\title{
The Bologna Process and HEIs Institutional Autonomy
}

\author{
By Linda Helén Haukland ${ }^{*}$
}

\begin{abstract}
The Bologna Process has made a strong impact on the development of European higher education, although the greatest impact has not been from the process itself, but from the national reforms introduced along with it. With a relatively young higher education system, Norway was ahead of most European countries in implementing the Bologna Process and reforms indirectly linked to it. Due to path dependencies and the Higher Education Institutions being, to a certain extent, autonomous and carriers of their own culture, we cannot draw conclusions at the local level without empirical studies. Therefore, the case of Nord University shows us how this process directly and indirectly affected Higher Education Institutions in Norway. The Higher Education Institutions (HEI) integrated horizontally in an education system that was increasingly hierarchical and competitive. The need for standardisation in order to secure equality and efficiency, and the demand for greater autonomy in the HEIs was answered by strengthening some and weakening other forms of institutional autonomy along with the establishment of a new accreditation system. Three dimensions of autonomy are touched on in this study. Firstly, the question of who has decision-making power in the HEIs defines whether they are ruled by professional or administrative autonomy. Secondly, the question of the HEIs' mission is decided either by the HEI itself, representing substantive autonomy, or by external demands on production and external funding, representing what I call beneficial autonomy. Finally, the question of how the HEIs fulfil their mission decides whether they have individual autonomy or procedural autonomy. In the last case, the HEIs are given external frameworks, which, to a great extent, define how they are to carry out their mission in order to succeed. The development of higher education in Norway shows how the introduction of the accreditation system hampered different types of institutional autonomy and strengthened others, a development that also brought dilemmas and tensions related to academic freedom. The Bologna Process played the role of both supplier of terms and a catalyst for these dilemmas. One of the consequences in Norway was a development where former colleges gained university status, among them Nord University (University of Nordland) in 2011.
\end{abstract}

Keywords: Bologna, Higher education, Norway, Nord University, HEI autonomy.

\section{Introduction}

The European integration of higher education, which gained momentum from the 1960s onwards, has resulted in extensive national change processes. However, in relation to previous national higher education reforms, the reforms that have taken place in the wake of the Bologna Process, have been marked by a higher pace (Witte, Wende, \& Huisman, 2008, p. 229). This made room for a greater degree of change than that anticipated by North's model from 1990 (North, 1990). Analyses of these national change processes must include the influence of supranational organisations in order to present the whole picture (Gumport, 2008, p. 26; Zgaga, Teichler, Schuetze, \& Wolter, 2010, p. 14; Kyvik, 2009, p. 23). It is

*Senior Lecturer, Nord University, Bodø, Norway. 
also relevant, according to Gammelsæter, to take a closer look at countries outside Europe that have a hegemonic influence on these developments, such as the USA. However, that is outside the scope of this article (Gammelsæter, 2002, p. 10). The OECD and the EU have played key roles, both as drivers of and agenda setters for European development (Maassen \& Olsen, 2007; Gornitzka \& Langfeldt 2008; Witte, Wende \& Huisman, 2008; Kyvik, 2009).

The OECD's recommendations are based on empirical data and thus have a high degree of legitimacy (Gammelsæter, 2002, p. 10). This organisation has played an important role in the development of knowledge about higher education across national borders, which is a condition for the increasing integration of higher education systems in the West (Bleiklie, 2003). It has also played a key role in the overriding process of introducing goal and performance management in European higher education. According to Kyvik, the EU has played an important role in connection with the establishment of a common education market in Europe (Kyvik, 2009). After 1998, the European Commission increasingly set the agenda for the development of higher education in Europe (M. Castells, personal communication, May 15, 2014; Keeling, 2006).

This article takes a closer look at how the Bologna Process directly and indirectly affected the reforms of Norwegian higher education between 1998 and 2010, with respect to HEIs' autonomy. The Bologna Process was an initiative to harmonise higher education standards in Europe, which indirectly influenced the development of HEIs' autonomy.

Since national reforms also have unintended consequences at the local level and studies have shown that it is the HEIs with the lowest status that drive developments in the field, the process whereby Bodø University College became a university is used as a case. This took place in parallel with the Bologna Process. It serves as an example of how increased European cooperation in higher education contributed to increasing the autonomy of HEIs (Witte, Wende \& Huisman, 2008, p. 228). The development that culminated in university status and the establishment of Nord University (the University of Nordland) in 2011, was both directly and indirectly affected by the Bologna Process.

\section{Literature Review}

When it comes to the impact of the Bologna Process at the local level in Norway, a number of books are crucial to this study, both in order to understand continuity and new developments as well as key concepts. I will present some of them that have relevance to different parts of this study.

In the article "Governmental policy, organisational ideals and institutional adaption in Norwegian higher education" from 2006, Stensaker explores the relationship between the Government's intentions and the implications of education policy between 1990 and 2000, the period leading up to the Bologna Process. He traces a development towards the bureaucratic ideal in Norway due, among other things, to more centralised decision-making processes in the HEIs (Askling, 1997; Stensaker, 2006, p. 43). Another factor is the institutional implementation of 
external quality assurance and political guidelines in order to improve and secure the quality of teaching and learning, dominated by the European level (Kogan \& Hanney, 2000, p. 240). Stensaker (2006, p. 43) underlines that there is a gap between the governmental policies and their organisational implementation. In order to find effects at the local level, it is therefore crucial to study how the leaders make use of new room for manoeuvre in reforms, as well as their role in bringing meaning and direction to the organisational implementation process. This insight is the premise for my analysis.

One of the main theoretical sources that illustrate the historical development within the college sector in the Norwegian higher education system, is Svein Kyvik's book The Dynamics of Change in Higher Education. Expansion and Contraction in an Organisational Field from 2009, which provides crucial concepts and definitions for analysing the development of higher education in Norway.

Kyvik presents dynamics that follow different partially overlapping phases. One of these phases is when the HEIs became more similar due to a horizontal integration of the college sector where they became more strongly related to each other. Horizontal integration is defined as "de-differentiation and de-diversification of professional and vocational programmes in the college sector" (Kyvik, 2009, p. 81 ). In this phase, there was a reduction of colleges in the sector due to mergers, and the college sector was separated from the university sector in a binary system (Kyvik, 2009, p. 9). Another phase took place during the Bologna Process in Norway and differed from most other western countries. Here, academic and vocational drift met in a more or less unified education system where universities offered most educations, both academic and professional (Kyvik, 2009, p. 10). Kyvik (2009) defines, like other researchers in the field of higher education, the education system along two dimensions: in relation to the state and in relation to other HEIs. In this article, I present a third dimension, defining higher education systems also along the dimension of society at large.

\section{Theoretical Perspectives and Sources}

In this article, I draw on an institutionalist perspective that takes account of the cultural, normative and formal changes that affected the field of higher education in Norway (DiMaggio \& Powell, 1983; Scott, 2014). This perspective enables us to take a closer look at the interaction between institutions, organisations and key persons at the national, regional and local level. The resource dependence theory is also used to highlight the tension between dependence on an institution's surroundings and the independence achieved by the institution through what we now call local entrepreneurship and network building (Pfeffer \& Salancik, 2003 [1978]). This combination produces a richer picture of the development of higher education (Gornitzka, 1999).

The impact of structural and cultural factors as well as the impact of interest groups has been crucial to this study. Structural explanations take, according to Kyvik (2009, p. 189) a closer look at "the impact of technological, economic, and 
social change in society on the organisation of human activity" in addition to changes generated by the education system itself. The theoretical paradigm structural-functionalism has been criticised for not explaining the mechanisms leading to change, among them conflict. What it does explain, is the growth in student numbers as a result of an expanding middle class and the expansion of new professions in the welfare state. Due to this paradigm, the transition from fragmented expansion to horizontal integration could, according to Kyvik (2009, p. 27), be explained as "a shift from a dysfunctional organisational structure to a more functional or effective way of organising this part of the educational system".

When it comes to cultural explanations, Kyvik highlights the role of norms and values in developing higher education systems as one theoretical approach. In this article, the values of social benefit, efficiency, quality and equal opportunities for education, by me called "the principle of equality", are given special attention (Haukland, 2018, p. 29). Another theoretical approach that is given weight is the influence of global ideologies on higher education systems, which implies that they change as a result. One key question here is whether they respond more to their global context than to their own cultural and social history. Finally, in addition to the specific local organisational culture, there is a tendency for organisations to copy each other (Kyvik, 2009, p. 189).

As structural and cultural explanations do not involve actors; "Structural development and cultural trends do not make decisions", Kyvik (2009, p. 29) underlines that there also has to be a third theoretical approach in order to reveal the dynamics of change on the field of higher education. The influence of interest groups is a perspective of power and conflict, and emphasises change as a product of interaction and power struggles. This study also uses this approach both at a local, national and European level (Haukland, 2018).

In the article "Governmental policies and organisational change in higher education" from 1999, Gornitzka presents a theoretical framework for comparative research on organisational change in the field of higher education. She bases her framework on both new institutionalism and on resource dependency, in order to understand how HEIs' economic frameworks and plans are affected by the policy and programme of the government. How do they change as a result of their response? Both theories have two basic prerequisites: "organisational choice and action are limited by various external pressures and demands, and the organisations must be responsive in order to survive" (Gornitzka 1999, p. 7). They differ, however, in to what extent and how they change.

The theory of resource dependency, first presented by Pfeffer and Salancik in 1978, highlights that organisations are flexible and basically oriented towards other organisations in order to protect their autonomy and decision-making power when they meet limitations and external control. They make active and independent choices firstly because their development is also dependent on them, secondly because they can lead and manipulate their dependency through alternative responses to external demands, and thirdly, the demands are not always consistent. They find themselves "in complex environments faced with competing demands" (Gornitzka, 1999). 
The new institutional approach has another viewpoint, emphasising stability and hindrances for changes within organisations. For example, March has shown that most organisational changes are the result of "relatively stable routine responses that relate organisations to their environments" (Gornitzka, 1999, p. 9; March, 1998). Gornitzka takes a closer look at why this is dependent on whether the reform is in line with the institutional identity of the organisation or not. What she calls "a normative match", a concurrence between values and prerequisites for change and the identity and tradition of the organisation, is, according to her, decisive in order for political initiative to generate organisational change (Gornitzka, 1999, p. 10).

Witte, Wende and Huisman's article "Blurring boundaries: how the Bologna process changes the relationship between university and non-university higher education in Germany, the Netherlands and France" from 2008 concerns how an overarching European process influences and limits the different national contexts affected by it. The authors show how this, among other things, led to political freedom of action at the national level to renegotiate the autonomy of HEIs (Witte, Wende, \& Huisman, 2008, p. 219).

The authors assert that the Bologna Process affected the relationship between HEIs and the State because the change of the degree structure at the national level paved the way for further changes to the education system:

"If the degree structures changes, this is an opportunity for policy makers and other stakeholders to reconsider the distribution of roles and status between the institutional types in the system ... Understanding the power struggles that took place means looking behind the surface of converging degree titles in Europe" (Witte, Wende, \& Huisman, 2008, p. 218).

According to Douglass North's model for institutional change, perceptions derived from an international context can lead to a more extensive change process than expected (Witte, Wende, \& Huisman, 2008, 219, p. 228; North, 1990). Although developments differed in the three countries and were strongest in Germany, the authors show that an integration of higher education took place in all of them. This article takes a closer look at this integration process in the Norwegian context.

Two of the sub-goals of the Bologna Process were to strengthen HEIs' autonomy and to increase efficiency in the field of higher education (Gaston, 2010, p. 66; Bleiklie, 2007, p. 98). Both of these goals were achieved through the establishment of the accreditation system, which was made possible through the strengthening of HEIs' institutional autonomy in connection with the 1994 Norwegian college reform (Elken \& Frølich, 2017, p. 104). However, the increasing complexity of the field necessitates taking a closer look at the type of institutional autonomy that was strengthened through the different national reform processes in connection with the Bologna Process.

There are basically three types of institutional autonomy. The first concerns whose decision-making power is strongest when an institution's autonomy increases. Professional autonomy means that the academic staff have most decision-making power in the organisation, while administrative autonomy is 
defined by the organisation's central administration having most decision-making power (Etzioni, 1964, p. 75- 84; Schmidtlein \& Berdahl, 2011, p. 70). There is also a distinction between substantive and what I call beneficial autonomy, depending on what decision-making power the institution has over what the organisation will do. Fran A. van Vught (1996, p. 185) has defined substantive autonomy as the right to decide the institution's mission (Haukland, 2015, p. 207; S. Fossum, personal communication, January 4, 2011; F. Mellemvik, personal communication, April 22, 2014; E. Nilsen, personal communication, January 5, 2011; Figure 1). Beneficial autonomy means that HEIs have to raise part of their financial base from external clients and financial partners, and that HEIs' income is based on their production, primarily in the form of graduates and research products, in addition to external funding.

The third type of institutional autonomy relates to the extent to which the organisation itself decides how it achieves its mission. In that case, the mission is to ensure profitable operation rather than to develop and preserve the region, to develop counter-expertise based on regional knowledge development and to ensure the supply of an educated labour force also in rural areas (Yttri, 2010). A distinction is drawn here between individual and procedural autonomy, depending on whether the HEIs set their own limits, as in the case of individual autonomy, or whether their limits are set externally, and are thereby limited to exercising procedural autonomy (Torjesen, Hansen, Pinheiro, \& Vrangbæk, 2017, p. 80).

\section{Methodology}

As pointed out by W. Richard Scott (2014, p. 258, 270), historical presentations provide a more correct picture of whether change processes represent a break or continuity. A time frame also prevents analyses from being oriented towards dichotomies instead of insight into complexity. The Bologna Process did not represent a break, but a continuation of an overarching and comprehensive structural change at the European and national level in higher education (Neave, 2004, p. 12; Musselin, 2004, p. 37, Gammelsæter, 2002, p. 10). The analysis will therefore also be based on a longer time frame where relevant.

A large number of sources touch on this topic. Some local literature is available in the form of publications to mark anniversaries, reports and articles. I have studied key documents at Nord University, Bodø Archive, Nord University, Nesna Archive, the National Archives of Norway in Trondheim and Nordland Archive, as well as articles relating to the process of becoming a university in the local press. At the national level, Official Norwegian Reports, white papers, parliamentary deliberations and draft resolutions and bills are central sources that have been reviewed, as have historical accounts of higher education in Nordland, in particular, and of higher education, in general.

One of these is my book Nye høyder. Framveksten av Universitetet $i$ Nordland ("New Heights. The development of the University of Nordland") from 2015, which is based on archival studies in national and regional archives, along with interviews, covering the development in expertise and higher education in the 
city of Bodø from the 1850s up until the establishment of the University of Nordland, now Nord University, in 2011.

I also rely heavily on around 40 semi-structured interviews conducted with faculty and leaders at Bodø University College and other HEIs about the process leading up to university status in 2011 (Haukland, 2018). Some of the interviews are with external actors. The interaction between the local and European level has been examined through these interviews, as well as other sources.

\section{Discussion: Norwegian HEIs' Autonomy}

The interviews reveal that the institutional development at Bodø University College was regarded as a regional democratisation of knowledge with the degree of institutional autonomy serving as both a limiting factor and driver. Based on these dimensions, the analysis will therefore look more closely at the increase in institutional autonomy at Bod $\varnothing$ University College, and how it affected the process of becoming a university.

When Bodø University College was established in 1994, following a merger between the city's teacher training college, nursing college and Nordland College, the new institution had much greater autonomy than the former colleges. The three former colleges nonetheless felt a loss of autonomy because they now had to coordinate their activities under the same leadership and within a new framework. The biggest challenge for the leadership of the new university college was therefore to establish a common organisational culture. The process of becoming a university was seen as a key strategy in order to achieve a shared identity.

At the national level, the problem was how the increasing focus on quality assurance in the field could both follow up national priorities and ensure greater institutional autonomy. An evaluation report from 1999 in connection with the college reform stated that "it is ... difficult to envisage strong national control and a high degree of local autonomy being achieved at the same time, while it is fully possible in theory to simultaneously increase efficiency and improve the quality of work at the institutions" (Kyvik, 1999, p. 6). Quality assurance was not linked to national priorities at that time.

\section{Decision-making Power: Professional vs. Administrative Autonomy}

When the university process started in 2000, the goal of becoming a university meant that the institution would become part of the university sector and enjoy a higher degree of professional autonomy in a binary education system. The academic staff held on to this perception until the process of becoming a university was concluded. The different academic communities, with their different college cultures, saw the plans to become a university as a strategy to win back the autonomy they had lost in the 1994 merger (Høgskolestyret i Nordland, 1990). For example, the academic staff at the Faculty of Teacher Education and at the Faculty of Health Sciences had a strong wish to safeguard the vocational drift of each programme of professional study (E. Nilsen, personal communication, January 5, 
2011). Achieving this within the framework of the new institution was challenging, since academic drift was seen as the mark of a good academic environment and institutional autonomy entailed more administrative and less professional autonomy. Academic drift is in this article used as a term for general academisation processes in the college sector (Kyvik, 2007). Until the merger in 1994, the two programmes of professional study had institutional autonomy, with administrative and professional autonomy being largely correlated. However, this changed in connection with the merger as the rector was no longer recruited from these academic communities (Karlsen, 2005, p. 410).

Their support for the university process was based on the assumption that university status would increase their professional autonomy through the right to develop master's and $\mathrm{PhD}$ programmes (R. H. Olsen, personal communication, December 20, 2010; M. Rasch, personal communication, December 21, 2010; E. Nilsen, personal communication, January 5, 2011; B. S. Brinchmann, personal communication, February 4, 2011). The interview material shows that they did not distinguish between the previously mentioned different types of institutional autonomy, which led to an expectation that greater institutional autonomy would be synonymous with greater professional autonomy. As mentioned, however, it was in reality administrative autonomy that increased at the university college. Greater institutional autonomy concentrated in the central administration enabled Bodø University College to implement the changes the process of becoming a university required. Stensaker regards this as part of the bureaucratisation process because decision-making processes in the institutions became more centralised (Askling, 1997, p. 17-26; Stensaker, 2006, p. 43).

The plans to become a university presented a new opportunity to win back professional autonomy because university status meant that the academic communities could establish $\mathrm{PhD}$ programmes themselves. All of the academic communities regarded an increase in professional autonomy as a strong motivation for the process of becoming a university. The fact that the academic staff saw university status as being synonymous with an increase in their professional autonomy may explain why few of them opposed the goal of becoming a university, despite the process generating major change processes within the institution (Haukland, 2015, p. 144).

Quality assurance has been highlighted as "the most potent of change agents" (Kogan \& Hanney, 2000, p. 240; Stensaker, 2006, p. 44). The development in Norway was part of an overarching trend in Europe, where the need to establish a regulated and independent accreditation body became more pronounced as the 1990s progressed. In extension of this work, in which Denmark, France, the Netherlands and the UK played important roles, the European Commission established the European Network for Quality Assurance in Higher Education (ENQA) in 2000 with the goal of establishing a common education market with harmonised degrees, grades and quality requirements. In the same year, the Mjøs Committee recommended that Norway should be part of this development. The establishment of the accreditation system generated many unintended consequences, however, that went beyond assuring academic quality. One of the 
consequences was that it made it easier for university colleges with ambitions to become universities to enter the university sector (Elken \& Frølich, 2017).

As we have seen, the distinction between different types of institutional autonomy provides insight into the organisational changes that took place in connection with the Norwegian college reform, and partly explains why both the leadership and academic staff at Bodø University College championed the process of becoming a university. This was an important precondition for succeeding. The fact that the strongest academic communities in the college sector - at Stavanger University College, Agder University College (with its main campus in the city of Kristiansand) and Bodø University College - actively participated in the process of becoming universities could also explain why there was such a strong consensus on the major reform changes in the field in connection with the Quality Reform Programme in 2003, a reform that is regarded as having introduced the Bologna Process in Norway, and the establishment of the independent national quality assurance body Nokut the same year (Haukland, 2017, p. 8). These university colleges had the greatest potential to delay the process, but they were keen to realise the plans to become universities and thus to also agree other central requirements from the central authorities, rather than holding back the process.

In the Mjøs Committee's recommendation from 2000, which formed the basis for the reform, institutional autonomy and quality assurance were two of the key dimensions that were to be coordinated within a new framework:

"It is important ... to find organisational and management models that strike an expedient balance between the institutions' wish for more freedom and responsibility and overall control, coordination and quality assurance." (Kirke, utdannings-, og forskningsdepartementet, 2000, p. 51)

This balancing act resulted in greater, but increasingly limited institutional autonomy (Neave, 2004, p. 22). Through the Quality Reform, Bodø University College's central administration gained even more control of the institution's activities (Elken \& Frølich, 2017). This was a part of the European development in the field, with the exception of England, where HEIs already functioned as autonomous units.

According to Ivar Bleiklie, the Quality Reform led to educational institutions increasingly functioning as special interest organisations "in which power is transferred from the academic staff and other employee groups to appointed leaders and external stakeholders" (Bleiklie, 2007, p. 98). This power shift meant that, while the academic communities developed higher degree programmes to either recover lost or win new professional autonomy, they also lost control of the development of the institution (Haukland, 2015, p. 206).

One example that illustrates how the establishment of Nokut undermined professional autonomy was the development of external requirements for $\mathrm{PhD}$ programmes that were made applicable to the whole field of higher education. At the same time, it facilitated greater institutional autonomy through the establishment of regulations for the transition from university college to university status (Nokut, 2006). University status was thus no longer synonymous with greater professional autonomy. It rather led to greater administrative, but also 
diminished professional autonomy. Nevertheless, the accreditation system was important in relation to Bodø University College's process of becoming a university because it meant that both the administration and the academic staff had the same objectives for the work on gaining university status. The interview material shows that there was strong support for the process within the organisation also after 2003, probably based on lack of insight into the shift from professional to administrative autonomy in the university sector.

According to John Brennan and Tarla Shah, quality assurance can "undermine existing academic cultures by weakening the boundaries between groups within HEIs" (Brennan \& Shah, 2000, p. 119; Stensaker, 2006, p. 44). This was what transpired; the leadership and academic staff cooperated closely on the development of $\mathrm{PhD}$ programmes between 2000 and 2009 in order to meet Nokut's requirements (Haukland, 2015, p. 147).

It was not just the perception that university status entailed professional autonomy that motivated the academic staff. This group also saw becoming a university as a means of securing their academic freedom, and the interview material also shows that these two aspects were regarded as the same thing. University status meant being able to establish master's and $\mathrm{PhD}$ programmes without having to apply to the Ministry. However, the transition to the accreditation system meant that external requirements also applied to these programmes at the universities, so that the academic freedom the academic communities sought was in reality not achieved. Instead, the $\mathrm{PhD}$ programmes that were already established had to be consolidated, rather than new programmes being introduced.

A report from Workshops on Higher Education Reform (HER) from 2010, states, among other things, that "(i)nstitutional autonomy has been given a new dimension, but there is a rising suspicion that it occasionally comes into conflict with academic freedom ..." (Zgaga, Teichler, Schuetze, \& Wolter, 2010, p. 20). In democratisation processes, there will always be factors that act in parallel with and challenges the original intention. The standardisation of the field had this effect on the university process. While the academic leadership of the faculties primarily saw the process as a means of achieving professional autonomy, the academic staff primarily regarded university status as a means of achieving greater academic freedom. Academic freedom can be defined both individually and collectively, and it is linked to the content and results of research. Collective academic freedom is safeguarded through professional autonomy, while individual academic freedom is not necessarily either safeguarded or undermined by it.

When academic freedom is to be organised, it is often defined as professional autonomy, to ensure that decision-making power rests with the academic staff and not with the central administration. The struggle for the professional autonomy of one's own academic community can thereby overshadow or be confused with the struggle for individual academic freedom. There are no examples in the interview material of a distinction being drawn between the two. Professional autonomy and academic freedom were seen as the same thing during the university process. This partly explains the strong institutional will and the strong internal cooperation at Bodø University College during the university process (Haukland, 2015, p. 145). 


\section{Mission Control: Substantive vs. Beneficial Autonomy}

For the university college's central administration, the process of becoming a university was primarily a struggle to strengthen the institution's possibility of influencing its development, even when the future is uncertain, by strengthening their aforementioned substantive autonomy, i.e. the right to decide the institution's mission (van Vught, 1996, p. 185; Stensaker, 2006, p. 44; Haukland, 2015, p. 207; S. Fossum, personal communication, January 4, 2011; F. Mellemvik, personal communication, April 22, 2014; E. Nilsen, personal communication, January 5, 2011; see Figure 1). To achieve university status, the university college first had to meet and function in accordance with the requirements made of Norwegian universities. In many ways, it had to present itself as a autonomous university before it could actually become one. The university college achieved this by, among other things, strengthening its "third mission".

"The third mission" is the term used for HEIs' responsibility for regional economic development, which Casper (2013, p. 1313) has highlighted as an important part of their relationship with society. Research activity with a regional focus and the study programmes' relevance to the labour market have been particularly highlighted in this context, as a source of new technology and knowledge in the region. "The third dimension" is a spill-over effect that promotes society and the business community, and, according to Casper, is strengthened by the institutions' network building and personal contacts in the region.

The reform developments in the field during the period paved the way for a stronger third mission in the college sector (Gammelsæter, 2002, p. 25). How and to what extent this affected the university college says something about how it operated as an autonomous institutional entrepreneur in contact with its surroundings during the process of becoming a university. The important aspect here is the ability to combine symbolic or material resources in new ways. The university college's regional networks were one of the preconditions if the fight for local transitional schemes was to result in the transformation of the institution from a university college into a university.

The university colleges' contribution to regional economic development was an important part of their relationship with society. Their role as region builders generated external funding for the college sector, which strengthened their position as autonomous parties and their institutional entrepreneurship because they could increasingly act independently of state funding. This was decisive in the process of becoming a university, since the university college received no funding from central authorities in order to achieve its goal (M. Rasch, personal communication, December 21, 2010; F. Mellemvik, personal communication, December 15, 2010; S. Fossum, personal communication, December 15, 2010). Both research activity with a regional focus and study programmes of relevance to the labour market were important to the success of "the third mission", which was strengthened by a number of factors.

First, the institution was strongly involved in building networks and cultivating personal contacts in the region throughout the period (Haukland, 2015, p. 212). This was crucial if regional research results were to benefit the business 
community and society at large, and for identifying and addressing the need for new study programmes (Norsk institutt for by- og regionforskning [Institute for Urban and Regional Research], 2000, p. 56). Bodø University College had an advantage here due to its central location, geographically and politically, in the capital of the county, and its proximity to other infrastructure in the region.

Both the rector and director of Bodø University College were strong network builders who were in contact with central authorities and "second order actors" at the local and national level (Kyvik, 2009, p. 22). However, the process of uniting the region behind strong institutional development in Bodø also encountered challenges. Towns in the north and south of the county were experiencing a decline in population and in the business sector, while there was strong growth in Bodø. This challenged the cooperation on Nordland as an entity and Bodø as a regional centre for higher education, and thereby also the horizontal integration of university colleges in Nordland. The county was one of two counties to retain more than one university college following the university college reform of 1994 . Narvik University College was situated in the north of the county, while Nesna University College was situated in the south.

The establishment of decentralised campuses in Tysfjord, in Helgeland and in Vesterålen was a way of taking responsibility for the development of the supply of an educated labour force in rural areas (Haukland, 2015, p. 221). This was an expression of institutional regionalisation, at the same time as study programmes were decentralised, a dynamic that Kyvik (2009, p. 10) believes promotes vertical integration defined as the shift from "the long period of geographical decentralisation of non-university institutions ..." to a period of regionalisation (Kyvik, 2009, p. 81). Narvik University College and Nesna University College saw the development of a university in Bodø as a threat to their autonomy (Haukland, 2015, p. 182). Bodø University College's decentralised campuses, with up to 500 students, were nonetheless involved in generating support for the university process in the region (M. Rasch, personal communication, December $21,2010)$. The university college emerged as an autonomous actor with a will to develop Nordland.

As we have seen, greater institutional autonomy was to be balanced with greater overarching control, coordination and quality assurance by the Ministry. As well as further strengthening the importance of the central administration as a local facilitator, it also made a strong contribution to the standardisation of quality assurance criteria and systems. Substantive autonomy was thus weakened in favour of beneficial autonomy where "the third mission" played a key role in building networks in the region and in raising funding for the process of becoming a university. In many ways, it enjoyed greater substantive authority as a university college than after it secured university status, because it then had to be defended in accordance with Nokut's regulations relating to Norwegian universities, although the quality requirements applied to both sectors. 


\section{The Surprise: Individual vs. Procedural Autonomy}

The standardisation encouraged more competition between the institutions, which, in turn, strengthened the horizontal integration previously driven by academic drift and equality requirements in the college sector. The universities and colleges had become comparable entities, and they could be ranked based on a common set of criteria, which led to a stronger hierarchisation of the field, where institutional diversity was sacrificed due to stronger competition. The goal was to be more like the HEIs with the highest status.

This hierarchisation of the field enabled the best HEIs in the college sector to qualify for university status (Fulsås, 2000, p. 396; Haukland, 2018). Individual autonomy was weakened in favour of procedural autonomy, and expertise trumped representativeness with regard to the division of labour (Jonsson, 2006, p. 28). According to Kyvik (2007, p. 334), this new competition led to a strengthening of different types of academic drift in the institutions.

However, the fact that Bodø University College gained greater administrative autonomy, and greater influence on the development of the institution, did not mean that the leadership gained more substantive autonomy, which is characterised by decicive power regarding the institution's mission. In connection with the Quality Reform, elements of both professional and substantive autonomy were transferred to Nokut during the university process, and its administrative autonomy was instead accompanied by greater procedural autonomy (see Figure 1). Instead of determining the institution's mission, the leadership's task was now to decide how the mission was to be achieved within a given external framework. One of the success criterias was to expand the "third mission".

It can be argued that this development ensured Bodø University College university status. Nokut's expert committees had an advisory function in the application processes for the $\mathrm{PhD}$ programmes in sociology, professional praxis and in aquaculture, which was decisive in relation to their approval (Haukland, 2015). The development of three of the $\mathrm{PhD}$ programmes, campus facilities, a new quality assurance system and satisfactory student welfare arrangements increasingly resembled procedures, which have to meet pre-defined requirements. Nokut's regulations served as a blueprint for the university in the making. Following the introduction of the regulations on minimum standards for Norwegian universities in 2006, the process of becoming a university mainly focused on meeting the detailed requirements for writing an application for university status that would win approval.

The establishment of Nokut meant that academics were granted decisionmaking powers on different expert committees, but they did not decide what they were to make decisions about or on which criteria they were to base their decisions. The professional autonomy of Nokut therefore takes on a veneer of organic order through stronger administrative and procedural autonomy in the institutions. Organic order is here understood as when the relation between the HEIs is defined by different functions and tasks through specialization (Bleiklie, 2003, p. 342). At the same time it promotes both an "output" order aimed at ensuring efficiency and quality pursuant to given standards in higher education, 
and a hierarchical order, where ranking is based on the degree of academic drift in the institutions. According to Bleiklie (2003, p. 341), organic order is weakened in favour of a hierarchical order in relations between HEIs when university colleges offer PhD programmes.

As previously mentioned, the interview material shows that the academic communities did not distinguish between the different types of institutional autonomy. This can partly explain why few people opposed the university plans, despite the process generating extensive change processes at the institution (Haukland, 2015, p. 144). In reality, a stronger institutional autonomy that was concentrated in the central administration following the Quality Reform increased Bodø University College's ability to implement changes. While the academic communities developed higher degree programmes to achieve greater professional autonomy through university status, they also lost control of the development of the institution (Haukland, 2015, p. 206). According to Bleiklie (2007, p. 98), the Quality Reform led the HEIs to increasingly function as special interest organisations "in which power is transferred from the academic staff and other employee groups to appointed leaders and external stakeholders." Their contribution to the university process was decisive, but the premises on which they were originally based changed after the establishment of Nokut. The academic communities thus did not gain the professional autonomy on which their support for university status was based.

\section{Three Dimensions of Autonomy}

As we have seen, the central leadership and the faculties of the HEI Bod $\varnothing$ University College had different aspirations for cooperating in the university process leading to the establishment of the University of Nordland, now Nord University, in 2011. While the central administration aimed for greater institutional autonomy for the leadership and faculty, the faculty members looked at the university process as an opportunity either to win back professional autonomy lost in the merger leading to the establishment of Bodø University College in 1994, or to strengthen it. The process was made possible partly by the changes following, directly and indirectly, from the Bologna Process. The Norwegian Quality Reform Programme did not only entail the implementation of the Process, but was also the answer to several challenges in the field of higher education in Norway, among them the university aspirations of the strongest university colleges.

The different forms of institutional autonomy are displayed in three dimensions in Figure 1. The first dimension concerns who manages the decisionmaking power. During the Bologna Process, the centre of gravity relating to decision-making power not only shifted from faculty to central administration, it also shifted from the HEIs to different committees of Nokut. The second dimension concerns how the HEIs' tasks are performed. During the national integration processes following the Bologna Process, the individual autonomy of Norwegian HEIs was weakened in favour of procedural autonomy. Although the question of how the HEIs accomplished their mission was left to the institutions to a greater extent, they now had to satisfy stricter formal demands made by Nokut. The third 
dimension mainly went under the radar due to the new accreditation regime's lack of experience. The organisational culture of establishing and innovating new education programmes in Nordland, which strongly influenced the mission the HEI was to have in the region, was now threatened by the strong demands for economic growth. The substantive autonomy, which was assumed to be strengthened by the forthcoming university status, was replaced by a new beneficial autonomy for both colleges and universities alike.

The different forms of institutional autonomy are presented in Figure 1 below:

Figure 1. Different Types of Institutional Autonomy within Higher Education Systems

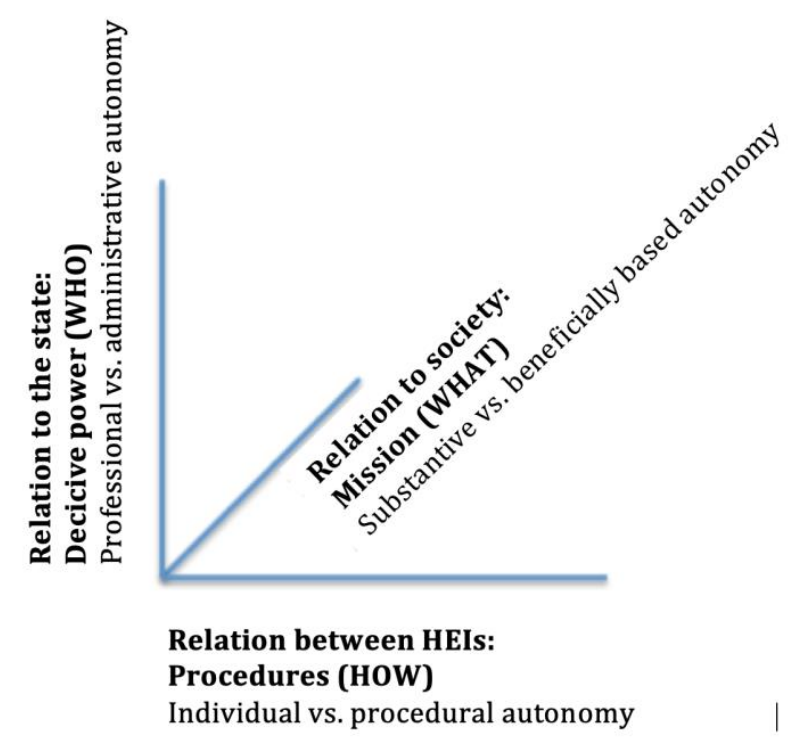

Source: Haukland, 2019. Based on (van Vught, 1996; Schmidtlein \& Berdahl, 2011; Torjesen, Hansen, Pinheiro \& Vrangbæk, 2017)

\section{Conclusions}

The Bologna Process has made a strong impact on the development of European higher education, although the greatest impact has not been from the process itself, but from national reforms introduced along with it (Stensaker, 2006; Witte, Wende, \& Huisman, 2008, p. 219, 228).

This article shows how the dynamics of change in higher education both at the European and Norwegian level affects the local level with respect to institutional autonomy.

As an indirect and direct result of the Bologna Process, the Norwegian binary education system changed into a more uniform education system. This was not generated from the relationship between the HEIs and between them and the state alone. Through stronger ties to society at large this was even generated from a third dimension, adding a tremendous complexity to the field. The development was achieved partly as a result of the university processes in Agder, Rogaland and 
Nordland, due to a lack of resistance from the three strongest HEIs in the college sector, in their struggle to cross the boarder to the university sector. It led to the establishment of new universities in Norway with a professional profile, among them the University of Nordland, which was subsequently merged into present Nord University.

One of the original central aims of the colleges aspiring for university status in Norway was, as for the faculty members, to enhance and strengthen their professional autonomy. For the central administration, the main focus was to strengthen the substantive autonomy of the institution, gaining mission control. However, as the field of education underwent great changes along with the Bologna Process, the faculty members both in colleges and universities lost their professional autonomy to the central administration of HEIs as well as Nokut. On the other hand, the central administration did not gain the substantive autonomy they pursued due to the establishment of Nokut, but increased their autonomy when it came to their "third mission" along with other both colleges and universities.

Although the HEIs' institutional autonomy has been strengthened, it has also become more restricted, resulting in a decrease in professional, individual and substantive autonomy. In other words, the faculty has lost much of its decisionmaking power, and the HEIs have to manage their mission and solutions pursuant to stricter external frameworks and demands for quantitative quality and efficiency. National priorities have become more influential. The new complex three dimensional education system is yet to be examined and defined, in this article I only highlight some of the consequences due to institutional autonomy.

There are certain dilemmas associated with this development. It may threaten the HEIs' status as core institutions of society, as long as their aim to enhance regional development is to a large extent redefined from developing both urban and rural areas to pave the way for economic development in regional cities. It also entails a dilemma for the academic freedom of faculty members as professional autonomy is partly transferred from the HEIs to the different professional committees in Nokut. This concern has also been raised regarding the European HEIs in general (Van Vught, 1996, p. 185).

\section{References}

Askling, B. (1997). Quality monitoring as an institutional enterprise. In Quality of Higher Education, vol 3, (pp. 17-26). Oxfordshire: Taylor \& Francis Group.

Bleiklie, I. (2003). Hierarchy and Specialisation: on the institutional integration of higher education systems. European Journal of Education, 38(4), 341-355. doi:10.1111/j. 0141-8211.2003.00153.x.

Bleiklie, I. (2007). The Social Foundations of the Evaluative State and the Universities as Stakeholder Organisations. In Towards a cartography of higher education policy change, Enders, J. \& van Vught, F. (eds.), (pp. 97-104). Enchede: Center for Higher Education Policy Studies. 
Brennan, J., \& Shah, T. (2000). Managing quality in higher education: an international perspective on institutional assessment and change. Buckingham: Open University Press.

Casper, S. (2013). The spill-over theory reversed: The impact of regional economies on the commercialization of university science. Research Policy, 42(8), 1313-1324. Philadelphia: Elsevier. doi= 10.1016/j.respol.2013.04.005.

DiMaggio, P.J., \& Powell, W.W. (1983). The iron cage revisited: Institutional isomorphism and collective rationality in organizational fields. American Sociological Review, 48(2), 147-160. Washington: Sage.

Elken, M., \& Frølich, N. (2017). Pulling the Plug in a Bathtub: The Big Consequences of a Small Change in Norwegian Higher Education. In Policy Analysis of Structural Reforms in Higher Education. Palgrave Studies in Global Higher Education, de Boer, H., File, J., Huisman, J., Seeber, M., Vukasovic, M. \& Westerheijden, D. F. (eds.), (pp. 95-117). Basingstoke: Palgrave Macmillian. doi= 10.1007/978-3-31942237-4.

Etzioni, A. (1964). Modern Organizations. New Jersey: Prentice-Hall.

Fulsås, N. (2000). Frå binært til hierarkisk system i høgare utdanning?. Historisk tidsskrift, 79(3), 385-396. Oslo: Universitetsforlaget. doi= 10.18261/issn.1504-2944.

Gaston, P. L. (2010). Challenge of Bologna: What United States Higher Education Has to Learn from Europe and why it Matters That We Learn It. Vancouver: Stylus Publishing.

Gammelsæter, H. (ed.) (2002). Høgskoler til besvaer. Når statlige reformer møter lokale institusjoner og ambisjoner. Bergen: Fagbokforlaget.

Gornitzka, А. (1999). Governmental policies and organizational change in higher Education. Higher Education, 38(1), 5-31. Dordrecht: Kluwer Academic Publishers. doi= 10.1023/A:1003703214848.

Gornitzka, A. \& Langfeldt, L. (eds.). (2008). Borderless Knowledge: Understanding the New Internationalisation of Research and Higher Education in Norway. Higher Education Dynamics, 22., Dordrecht, the Netherlands: Springer. doi= 10.1007/978-14020-8283-2.

Gumport, P.J. (ed.) (2008). Sociology of Education: Contributions and Their Contexts. Baltimore: Johns Hopkins University Press.

Haukland, L.H. (2015). Nye høyder. Framveksten av Universitetet $i$ Nordland. Stamsund: Orkana Akademisk.

Haukland, L. (2017). The Bologna Process: the democracy-bureaucracy Dilemma. Journal of Further and Higher Education, 41(3), 261-272. [digital edition 24.09.2015]). doi= 10.1080/0309877X.2015.1070403.

Haukland, L.H. (2018). Universitetet $i$ Nordland. Spenninger og samspill $i$ en høgskolesektor. Ph.D. dissertation. Bodø: Faculty of Social Sciences, Nord University.

Høgskolestyret i Nordland (1990). Høgskolemiljøet $i$ Bod $\phi$. Samarbeidsmål og Samlingsmuligheter [Report made by committee of representatives from the university colleges in Bod $\phi$ ].

Jonsson, G. (2006). Tanter och representanter. Dilemman i frivilliga organisasjoner - en fråga om oligarki eller demokrati? $\mathrm{PhD}$ dissertation. Umeå: Sociologiska institutionen, Umeå University.

Karlsen, G. E. (2005). Styring av norsk lærerutdanning: et historisk perspektiv. Norsk Pedagogisk tidsskrift, 89(6), 409-416. Oslo: Universitetsforlaget. doi= 10.18261/ issn.1504-2987.

Keeling, R. (2006). The Bologna Process and the Lisbon Research Agenda: The European Commission's expanding role in higher education discourse. European Journal of Education 41(2), 203-223. New Jersey: Wiley. 
Kirke, utdannings-, og forskningsdepartementet [The Ministry of Church Affairs, Education and Research]. (2000). NOU 2000: 14 Frihet med Ansvar. Om høgre utdanning og forskning i Norge. (Mjøs Committee).

Kogan, M., \& S. Hanney. (2000). Reforming Higher Education. London: Jessica Kingsley.

Kyvik, S. (1999). Høgskolereformen - et ledd i moderniseringen av Forvaltningen. In Evaluering av Hogskolereformen - sluttrapport (part 2.5), Kyvik, S. (ed.). Oslo: Norges Forskningsråd.

Kyvik, S. (2007). Academic drift - a reinterpretation. In Towards a cartography of higher education policy change, Enders, J. \& van Vught, F. (eds.), (pp. 333-338). Enchede: Center for Higher Education Policy Studies.

Kyvik, S. (2009). The Dynamics of Change in Higher Education. Expansion and Contraction in an Organisational Field. In Higher Education Dynamics, vol 27. Oslo: Springer.

March, J. G. (ed.) (1988). Decisions and Organizations. Oxford: Basil Blackwell.

Musselin, C. (2004). Commentary on Guy Neave. In Managerialism and Evaluation in Higher Education, vol 7, (pp. 35-38). Paris: UNESCO Forum Occasional Paper Series.

Maassen, P., \& Olsen J.P. (eds.) (2007). University dynamics and European integration. Dordrecht: Springer.

Neave, G. (2004). The Bologna Process and the Evaluative State: a Viticultural Parable. In Managerialism and Evaluation in Higher Education, vol 7, (pp. 11-34). Paris: UNESCO Forum Occasional Paper Series.

Nokut (2006). Forskrift om standarder og kriterier for akkreditering av studier og kriterier for akkreditering av institusjoner i norsk høyere utdanning (January 25). Oslo: Nokut.

Norsk institutt for by- og regionforskning [Norwegian Institute for Urban and Regional Research]. (2000). Høgskolenes regionale Betydning.

North, D.C. (1990). Institutions, Institutional Change and Economic performance. Political Economy and Institutions and Decisions. New York: Cambridge University Press.

Pfeffer, J., \& Salancik, G.R. (2003 [1978]). The External Control of Organizations: A Resource Dependence Perspective. Standford: Standford University Press.

Schmidtlein, F.A., \& Berdahl, R.O. (2011 [1999]). Autonomy and Accountability: Who Controls Academe?. In American Higher Education in the Twenty-First Century: Social, Political, and Economic Challenges, Altbach, P. G., Gumport P. J. and Berdahl, R. O. (eds.), (pp. 69-87). Baltimore: John Hopkins University Press.

Scott, W.R. (2014). Institutions and Organizations. Ideas, Interests, and Identities. Thousand Oaks: Sage.

Stensaker, B. (2006). Governmental policy, organisational ideals and institutional adaptation in Norwegian higher education. Studies of Higher Education, 31(1), 4356. London: Society for Research into Higher Education. doi=10.1080/0307507050 0392276.

Torjesen, D.O., Foss Hansen, H., Pinheiro, R., \& Vrangbæk, K. (2017). The Scandinavian Model in Healthcare and Higher Education - Recentralising, decentralising or both? Scandinavian Journal of Public Administration, 21(1), 57-80. Göteborg: School of Public Administration.

van Vught, F.A. (1996). The Humboldtian university under pressure: new forms of quality review in Western European higher education. In Inside Academia: new Challenges for the Academic Profession, Maassen, P. \& van Vught, F. A. (eds.), (pp. 185-226). Utrecht: De Tijdstroom.

Witte, J., van der Wende, M., \& Huisman, J. (2008). Blurring boundaries: how the Bologna process changes the relationship between university and non-university 
higher education in Germany, the Netherlands and France. Studies in Higher Education, 33(3), 217-231. London: Society for Research into Higher Education. doi $=10.1080 / 03075070802049129$.

Yttri, G. (2010). Motekspertisen og forminga av Sogn og Fjordane Distriktshøgskule. In Tankerekkjer - festskrift til Johs B Thue 70 år, Engesæter, Aa., Farda, J. I. \& Nes, L. (eds.), (pp. 51-62). Leikanger: Skald forlag.

Zgaga, P., Teichler, U., Schuetze, H.G., \& Wolter, A. (2010). Introduction. Reforming Higher Education for a Changing World. In Higher Education Reform: Looking Back - Looking Forward, Zgaga, P., Teichler, U., Schuetze, H. G. \& Wolter, A. (eds.). Frankfurt am Main: Peter Lang. doi= 10.3726/978-3-653-05441-5.

\section{Acronyms}

EF: De europeiske fellesskapene (1967-1993) [European Community]

ENQA: European Network for Quality Assurance in Higher Education from 2004: European Association for Quality Assurance in Higher Education)

EU: The European Union

Nokut Nasjonalt organ for kvalitet i utdanningen [the Norwegian Agency for Quality Assurance in Education]

HEI: Higher Education Institution

OECD: The Organisation for Economic Co-operation and Development 
